本セクションの発表を择聴して感じたこと法，各施設 とも，正確な LSF を求めるために苦労をしている上うで ある、正確な MTF を測定するため心は，正確なスリッ 卜像夜るい统LSFを求めることがまず出発点だと考え られる。このために学会としても何らかの対策を考えて も良いと思うが如何だろうか。

\section{画像理論 -2}

座長 川村義彦（日本医科大学病院）

\section{0。胸部腫瘤型陰影の検出について（第 2 報一密着撮影 と拡大撮影の比較)}

山口大学医学部附属病院放射能線部

$*$ 宇部與産中央病院

○橋田昌弘・大塚昭義・久米祐司* 山内秀一・上田克彦・横山 敬 中西 敬

胸部腫溜型陰影の検出能を ROC 曲線で比較検討した。 密着撮影では, Hiscreen(His)-RX, 拉大撮影では, His $-\mathrm{RX}, \mathrm{His}(\mathrm{Cu}$ filter)-RX, G8-RXOH, KH-AOL のシ ステムで, noduleの入った胸部ファントムを撮影し, 各 システムの心理的評価を行った。拡大撮影は密着撮影に 比べてかなり検出能が向上した。应大撮影すると, 各シ ステムの検出能に大きな差がなくなった。したがって， 拡大撮影では, 高感度の希土類システムを使用するのが 望ましい。また，フィル夕を付加すると， $I_{\text {max }}$ が約 18\% 增加し, 検出能が向上した，拡大撮影では，特にフィル 夕を付加することを十分俟討すべきと考える。

51. 一対比較法による X 線写真の主観的評価

奈良県立医科大学附属病院中央放射線部

・同がんセンター

○場 忍・大賀泰文・辻本武士

前田 要・宇山茂樹

〔目的〕頭蓋単純 X 線写真を, 心理学的評価法の一つ であるサーストンの一対比較法を用いて，濃度の主観に よる尺度化を試み，最適濃度域を検討した。

〔結果・考察〕得られた尺度行列より最適濃度域は 0.7 付近存在することがわかった。 そして，物理的尺度で 㹥均等に配列する刺激も，心理的尺度ではそうならない ことがわかった。をれに，心理的尺度上の刺激の間隔が

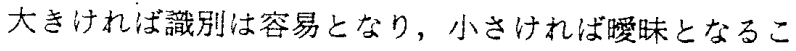
とが言える。

52. 好み（判断基準の差）による脳外科集団と放射線技 師集団の至適濃度の比較検討

奈良県立医科大学中央放射線部・同がんセンター
○前田 要・大賀泰文・音羽栄一 安藤英次・宇山茂樹

脳外科医集団と放射線技師集団の好みによる最適濃度 域を，第41回総会で報告した手法を用いて求めた。そのの 結果, 放射線技師集団の最適濃度域は cranium density : $0.8 \sim 1.2$, sinus density : $1.8 \sim 2.1$ にあり, 专の平均中心 点は（1.0，1.94）であった。脳外科医集団のそれに cranium density: 1.3 , sinus density 1.8 の点として存 在した。これより，脳外科医集団は cranium density が 黒い方を好むことがわかった。

53. 好み（判断基準の差）からみた増感紙・フィルム系 の選択法

奈息県立医科大学附属病院中央放射線部・

$$
\text { 同がんセンター }
$$

○岡本俊成・吉峰 正・野儀明厷 吉岡孝之・吉川昌一・前田 要 宇山茂樹

〔目的〕われわれは，第41回総会にて官能検查を用い ることにより観察者が潜在的にもっているであろう適正 濃度を求め, この濃度域を現行の増感紙・フィルム系で は通らないことを示した。そこで今回, 求めた適正濃度 域を通る濃度曲線を得る特性曲線の推定を試みた。

〔結果〕官能険查を用いて求めた適正濃度とそれに対 応する強度比より理想特性曲線が作成できた。また，作 成した理想特性曲線により得られた濃度曲線汸, 求めた 適正濃度域を通った。

\section{座長集約}

このセッションでは, 臨床 X 線写真の心理的主篗評価 の 4 題の発表がなされた．いずれも前回の総会からの続 報であり, 山口大学, 大塚らの研究グループを, 奈良医 科大学, 宇山らの研究グループによるものである。

演題500胸部腫瘤型陰影の検出（第 2 報, 密着撮影と 拡大撮影の比較）の山口大学, 橋田らは, 前回に引き続 き信号検出理論，ROC曲線で比較したものである。結論 は従来の考元方，見方の正しさを実証する形で，拡大撮 影での高感度希土類システムの有効性を報告した。さら に密着撮影, 拉大撮影ともに付加フィル夕によって検出

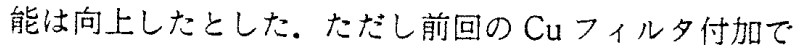
は感度は向上し，特異度は低下するという，いわば読み 過ぎの傾向を指摘した結論になっていたのに対し，今回 の実験結果は, 感度, 特異度ともにすべて向上したとし た.この両者の違いに対して改めて検定, 考察を加えた いとしており，今後の研究のまとめを期待したい.

演題51の一対比較法によるX 線写真の主観的評価, 奈 